\title{
Providing Stability to High Internal Phase Emulsion Gels Using Brewery Industry By-Products as Stabilizers
}

\author{
Adrián López-García, Gemma Moraga (D), Isabel Hernando * (D) and Amparo Quiles \\ Departamento de Tecnología de Alimentos, Universitat Politècnica de València, 46022 Valencia, Spain; \\ adlogar2@etsii.upv.es (A.L.-G.); gemmoba1@tal.upv.es (G.M.); mquichu@tal.upv.es (A.Q.) \\ * Correspondence: mihernan@tal.upv.es
}

\begin{abstract}
The modern brewing industry generates high amounts of solid wastes containing biopolymers-proteins and polysaccharides — with interesting technological and functional properties. The novelty of this study was to use raw by-product from the brewing industry in the development of high internal phase emulsion (HIPE) gels. Thus, the influence of the emulsion's aqueous phase $\mathrm{pH}$ and the by-product's concentration on structural and physical stability of the emulsions was studied. The microstructure was analyzed using cryo-field emission scanning electron microscopy. To evaluate the rheological behavior, oscillatory tests (amplitude and frequency) and flow curves were conducted. Moreover, the physical stability of the emulsions and the color were also studied. The increase in by-product concentration and the $\mathrm{pH}$ of the aqueous phase allowed development of HIPE gels with homogeneously distributed oil droplets of regular size and polyhedral structure. The data from the rheology tests showed a more stable structure at higher $\mathrm{pH}$ and higher by-product concentration. This study widens the possibilities of valorizing the brewing industry's by-products as stabilizers when designing emulsions.
\end{abstract}

Citation: López-García, A.; Moraga, G.; Hernando, I.; Quiles, A. Providing Stability to High Internal Phase Emulsion Gels Using Brewery Industry By-Products as Stabilizers. Gels 2021, 7, 245. https://doi.org/ $10.3390 /$ gels7040245

Academic Editors: Patricia Lopez-Sanchez and Anna Ström

Received: 26 October 2021

Accepted: 29 November 2021

Published: 1 December 2021

Publisher's Note: MDPI stays neutral with regard to jurisdictional claims in published maps and institutional affiliations.

Keywords: oil structuring; physical stability; stabilizers; structure; biopolymers; rheology; cryo-SEM; vegetable oils

\section{Introduction}

Food and by-product management is one of the main challenges that the agroindustrial sector faces in the 21st century. Modern brewing is an industry producing high amounts of by-products, including solid and liquids. Throughout the process, diverse solid wastes are produced, mainly spent grains, trub, and spent yeast [1].

Trub is an effluent mainly composed of hop particles, colloidal proteins, and residual beer liquor. Spent yeast comprises excess yeast recovered from sedimentation in the tank. Trub and spent yeast generation can reach 0.4 and $3 \mathrm{~kg}$ per hL of beer, respectively [2]. Valorizing by-products is a promising strategy to reduce the wastes and to produce new added value ingredients or components [3]. To date, these beer by-products are mostly used as animal feed [4]. However, there is a trend trying to valorize them, such as their use in food supplements and functional foods [5], as a stored food insect protector [6], as antioxidant and antimicrobial [7] and to be used as free fat protein [8].

Trub is a source of fiber and protein, obtained from spent hops and the wort cooking, where proteins denature [7]. Spent yeast is also a source of lignocellulosic components and rich in proteins [9]. The emulsifying properties of spent yeasts have already been investigated and are attributed to $\beta$-D-glucans and mannoproteins [10]. Authors have evaluated the potential use of isolated mannoproteins and glucans from spent yeast as a fat replacer in mayonnaise and salad dressings as well as a carrier for microencapsulation [11-14]. Saraiva et al. [11] isolated protein from trub to produce high protein ice cream, Silva Araujo et al. [12] extracted $\beta$-glucan and mannoproteins from brewer's yeast to replace xanthan gum in mayonnaise, de-Melo et al. [13] used mannoproteins from discarded brewer's yeast in the formulation of a salad dressing to substitute syntethics agents, 
Paramera et al. [14] summarized the possibilities of using yeast cells for microencapsulation and Worrasinchai et al. [15] applied $\beta$-glucans from spent brewer's yeast as a fat replacer in low calorie mayonnaises. However, none have evaluated the possibility of directly using beer by-products, without isolating carbohydrate or protein compounds, to produce high internal phase emulsion (HIPE) gels. HIPEs are a type of emulsion in which the volume of internal phase exceeds the close packing limit $(\varphi>0.74)$ inducing conformational changes in droplets shape due to the relatively low Laplace pressure [16]. These conformational changes produce "solid-like" systems exhibiting viscoelastic properties, which allow the structuring of non-plastic fats, such as vegetable oils, using a direct approach [17]. Because of the high degree of packing, these emulsions are highly resistant to creaming or sedimentation [16]; furthermore, the high degree of packing caused by the elevated internal volume fraction allows these systems to encapsulate, protect, and deliver bioactive compounds in high concentrations [18-20]. Moreover, concentrated emulsions may mimic the functionality of saturated plastic fats [21]. Replacing saturated fat in food products is challenging as this type of fat shows good oxidative stability and solid lipid functionality. In this context, emulsion gels have been used to fully replace margarine in cakes obtaining comparable functionalities and sensorial properties than non-replaced cakes [22].

Harnessing plant based agro-industrial by-products as sustainable raw materials is very attractive, but it is time and energy-consuming because of the need to purify the desired compounds [23-26]. Herein, we worked with a mixture of trub and spent yeasts without modification, except for drying. To the best of our knowledge, there is no evidence of non-modified by-products used to produce HIPEs. However, using by-products to stabilize emulsions is a potential area of research and, recently, it has been studied to produce other type of emulsions, such as Pickering emulsions [27].

This study aimed to structure sunflower oil to obtain HIPE gels using brewing industry by-products as stabilizers. This study focused on understanding the effect of the $\mathrm{pH}$ of the aqueous phase and by-product's concentration on the emulsions' structural and physical stability.

\section{Results and Discussion}

\subsection{Powder's Characterization}

The water content of the powder was $3.70 \pm 0.07 \%$ and over half the particles $(53 \%)$ had a particle size between 90 and $106 \mu \mathrm{m}, 42 \%$ between 63 and $90 \mu \mathrm{m}$, and $5 \%$ between 45 and $63 \mu \mathrm{m}$. Color attributes were $\mathrm{L}^{*}=71.78 \pm 0.34, \mathrm{C}^{*}=32.25 \pm 0.63$ and $\mathrm{h}^{*}=85.11 \pm 1.68$.

\subsection{Microstructure}

Samples 9H, 12L, and 12H (as examples of limit values of $\mathrm{pH}-9$, the lowest and 12, the highest-and concentration- $\mathrm{L}$, the lowest and $\mathrm{H}$, the highest) were observed using the Cryo-FESEM technique to study the effect of $\mathrm{pH}$ and by-product concentration in the microstructure of the emulsions (Figure 1). The effect of $\mathrm{pH}$ was studied comparing samples $9 \mathrm{H}$ and $12 \mathrm{H}$. In the $9 \mathrm{H}$ emulsion (Figure $1 \mathrm{~A}-\mathrm{C}$ ), oil droplets were mostly big and embedded in a continuous matrix, mostly constituted of the by-product components. In this emulsion, oil droplet distribution and size were not homogenous. The continuous phase was likely generated through weak interactions between the biopolymers constituting the by-product. Sample 12H (Figure 1G-I) had a smaller oil droplet size than $9 \mathrm{H}$, and a droplet deformation, from spherical to polygonal, was observed. The surface of the oil droplets had a greater coating when $\mathrm{pH}$ increased, as observed when comparing Figure $1 \mathrm{~A}-\mathrm{G}$. In sample $9 \mathrm{H}$, a non-adsorbed polymeric network was observed that did not occur in sample $12 \mathrm{H}$. This might produce destabilization because of a weak interaction between polymers, producing bridging flocculation as shown in Figure $1 \mathrm{C}$, and thus indicate these by-products act as stabilizers when $\mathrm{pH}$ is increased. 

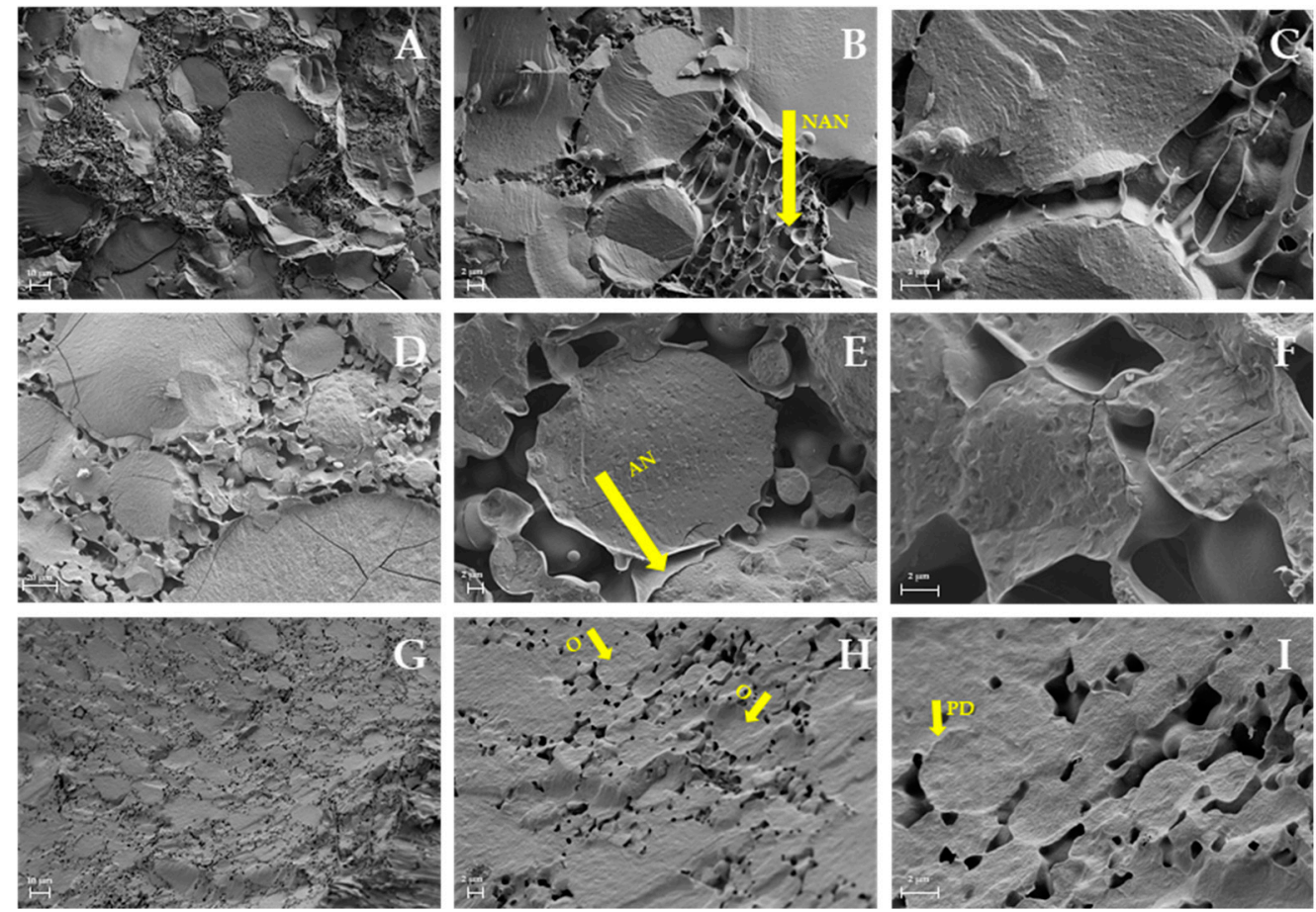

Figure 1. Microstructure of the emulsions observed using Cryo-FESEM. (A-C): $9 \mathrm{H}$ sample; (D-F): 12L sample; (G-I): $12 \mathrm{H}$ sample. (A,D,G): 500× magnification; (B,E,H): $2000 \times$ magnification; $(\mathbf{C}, \mathbf{F}, \mathbf{I}): 5000 \times$ magnification. Arrow NAN: non-adsorbed polymeric network; arrow AN: adsorbed polymeric network; arrow O: oil droplet; arrow PD: more polyhedric shape. (A,G) scale bar $10 \mu \mathrm{m}$; (B,C,E,F,H,I) scale bar $2 \mu \mathrm{m}$; (D) scale bar $20 \mu \mathrm{m}$.

To understand the influence of the by-product's concentration, samples 12L (Figure 1D-F) and 12H (Figure 1G-I) were compared. A heterogenous oil droplet size was observed in sample 12L; oil droplets were connected and separated by an interphase made by the interactions between the biopolymers from the by-product. The $12 \mathrm{H}$ emulsion showed smaller, more polyhedric shape, and more packed oil droplets than 12L with more structuring. It seems that the stabilizer effect of the biopolymers from the trub is higher when the concentration increases, and the $\mathrm{pH}$ is high. Increasing the amount of stabilizer usually increases HIPE gels stability until a limit of concentration, where an excess can be self-defeating [28]. Further research would be required to optimize the fabrication process of the end product, including gel dispersion within the food matrix.

\subsection{Rheological Behavior}

The rheological properties were analyzed to understand the influence of the $\mathrm{pH}$ of the aqueous phase and the by-product concentration on the emulsion stability. Amplitude sweeps gave the linear viscoelastic region (LVR) of the emulsions. The extension of the LVR of the different samples at $1 \mathrm{~Hz}$ is shown in Figure 2, where values of the elastic modulus $\left(G^{\prime}\right)$ and the viscous modulus $\left(G^{\prime \prime}\right)$ versus the shear stress wave amplitude are plotted. All samples had a higher $G^{\prime}$ than $G^{\prime \prime}$ at lower amplitudes, meaning the emulsions had a solid-like behavior. The sample with the lowest $\mathrm{pH}$ and by-product concentration (9L) was not characterized due to its instability. 

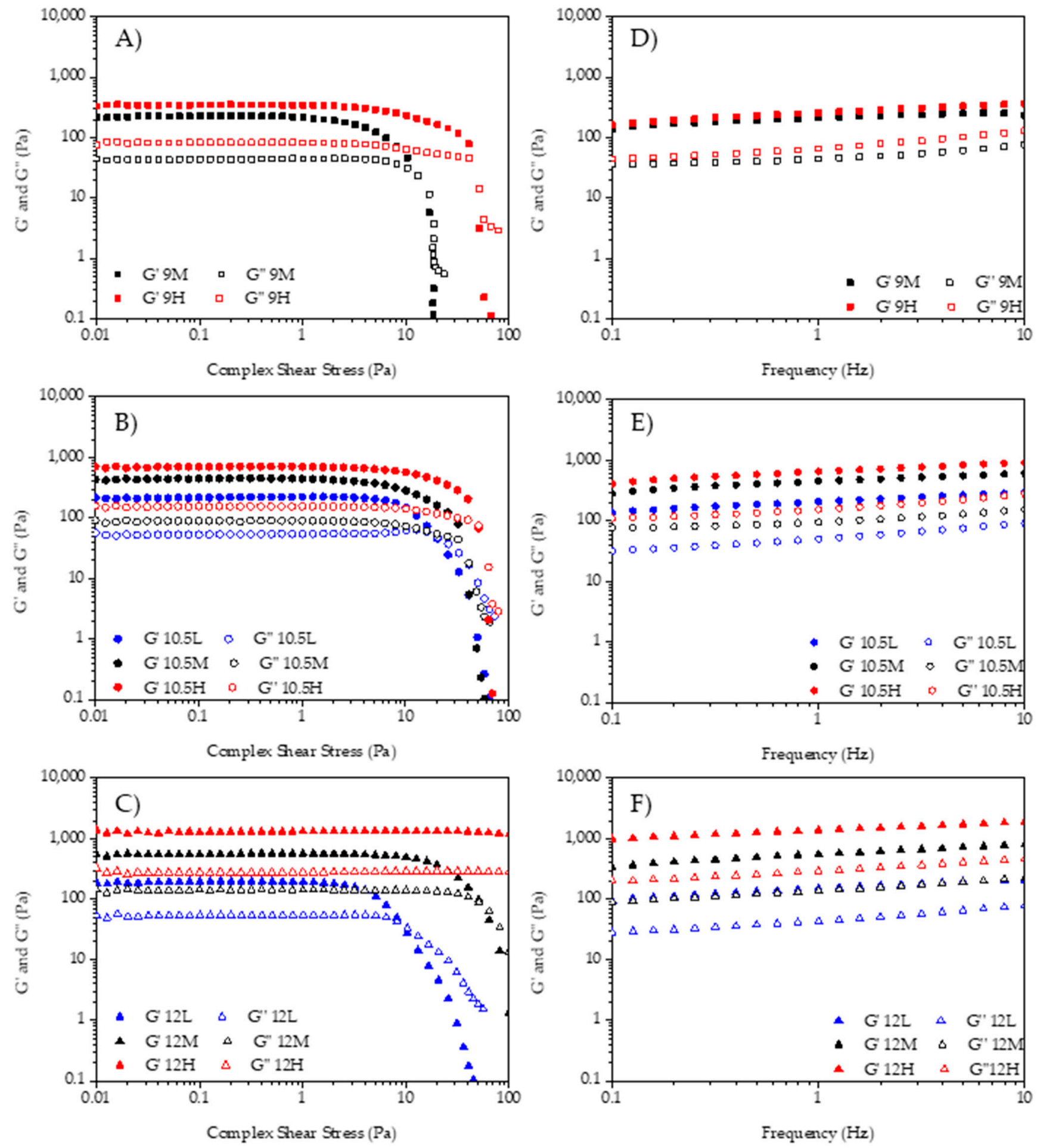

Figure 2. Rheological behavior of the emulsions. Left: amplitude sweeps; Right: frequency sweeps. (A,D) 9M and 9H; (B,E) 10.5L, 10.5M, and 10.5H; (C,F) 12L, 12M, and 12H.

The crossover point, where $G^{\prime}=G^{\prime \prime}$, appeared at amplitudes closer or higher than $10 \mathrm{~Pa}$ in all samples. This characteristic point-where the transition from solid-like to liquidlike behavior occurs-moved to higher stress values when $\mathrm{pH}$ and concentration were increased. This shift of the crossover to higher shear stress meant that at higher $\mathrm{pH}$ and concentration more stable HIPE gels were obtained, as higher stress values were needed to break down the internal structure. Figure $2 \mathrm{~A}$ shows that $\mathrm{G}^{\prime}$ of $9 \mathrm{H}$ was higher than $\mathrm{G}^{\prime}$ of $9 \mathrm{M}$ along the test and the crossover point's shear stress increased because of the by-products 
increased concentration. In Figure 2B, $\mathrm{G}^{\prime}$ showed the same behavior as Figure 2A and showed higher values when the concentration increased $(10.5 \mathrm{H}>10.5 \mathrm{M}>10.5 \mathrm{~L})$.

The crossover points of $\mathrm{L}, \mathrm{M}$, and $\mathrm{H}$ samples in Figure 2B showed less difference between them than $\mathrm{pH} 9 \mathrm{M}$ and $\mathrm{H}$ samples, but the $\mathrm{G}^{\prime}$ at these points was always higher as commented before.

Figure $2 \mathrm{C}$ shows the amplitude sweeps of samples $12 \mathrm{~L}, 12 \mathrm{M}$, and $12 \mathrm{H}$. $\mathrm{G}^{\prime}$ increased as the concentration of the by-product increased, as occurred in the other samples $(12 \mathrm{H}>12 \mathrm{M}>12 \mathrm{~L})$. The crossover point (flow point) showed greater stress differences between concentrations, as occurred in the $\mathrm{pH} 9$ samples when by-product concentration was higher; however, sample $12 \mathrm{H}$ did not flow nor break its structure.

Figure 2D-F show the mechanical spectra, or the relationship between the viscoelastic modulus as a function of the frequency at a constant stress of $1 \mathrm{~Pa}$ (within LVR). In all the emulsions, $G^{\prime}$ was higher than $G^{\prime \prime}$ along the entire range of frequencies studied and there was a low dependence between $G^{\prime}$ and $G^{\prime \prime}$ and the frequency. This indicates tightly packed systems with a solid internal gel structure where these parameters are governed by the bulk and the interfacial properties. When comparing the effect of the concentration in terms of structural stability, it is shown how increasing the amount of by-product increases the values of $\mathrm{G}^{\prime}$ and $\mathrm{G}^{\prime \prime}$. Thus, brewery wastes can be used as viable biopolymers to design concentrated emulsion.

For all the rheological parameters studied, there were significant interactions $(p<0.05)$ between the two factors by-product concentration and $\mathrm{pH}$ of the aqueous phase. The values of the viscoelastic modulus $\left(\mathrm{G}^{\prime}, \mathrm{G}^{\prime \prime}\right)$ at $1 \mathrm{~Hz}$ and $1 \mathrm{~Pa}$ are shown in Table 1.

Table 1. Rheological parameters of the emulsions.

\begin{tabular}{cccc}
\hline Sample & $\mathbf{G}^{\prime}(\mathbf{P a})$ & $\mathbf{G}^{\prime \prime}(\mathbf{P a})$ & Viscosity (Pa·s) \\
\hline $9 \mathrm{~L}$ & n.d. & n.d. & n.d. \\
$9 \mathrm{M}$ & $206(12)^{\mathrm{ab}}$ & $43(2)^{\mathrm{ab}}$ & $0.24(0.04)^{\mathrm{a}}$ \\
$9 \mathrm{H}$ & $261(19)^{\mathrm{bc}}$ & $67(4)^{\mathrm{bc}}$ & $0.56(0.02)^{\mathrm{c}}$ \\
\hline $10.5 \mathrm{~L}$ & $69(9)^{\mathrm{a}}$ & $19(2)^{\mathrm{ab}}$ & $0.24(0.03)^{\mathrm{a}}$ \\
$10.5 \mathrm{M}$ & $391(49)^{\mathrm{cd}}$ & $80(11)^{\mathrm{c}}$ & $0.67(0.04)^{\mathrm{d}}$ \\
$10.5 \mathrm{H}$ & $670(88)^{\mathrm{e}}$ & $160(16)^{\mathrm{e}}$ & $0.55(0.03)^{\mathrm{c}}$ \\
\hline $12 \mathrm{~L}$ & $78(6)^{\mathrm{a}}$ & $29(3)^{\mathrm{a}}$ & $0.41(0.03)^{\mathrm{b}}$ \\
$12 \mathrm{M}$ & $515(30)^{\mathrm{d}}$ & $129(6)^{\mathrm{d}}$ & $1.51(0.06)^{\mathrm{e}}$ \\
$12 \mathrm{H}$ & $1228(37)^{\mathrm{f}}$ & $248(41)^{\mathrm{f}}$ & $2.61(0.03)^{\mathrm{f}}$ \\
\hline
\end{tabular}

$\mathrm{G}^{\prime}$ and $\mathrm{G}^{\prime \prime}$ are determined at $1 \mathrm{~Hz}$ and $1 \mathrm{~Pa}$, and viscosity at $50 \mathrm{~s}^{-1}$. Different superscript letters within the same column mean significant differences between samples $(p<0.05)$.

When studying the effect of $\mathrm{pH}$ of the aqueous phase on $\mathrm{G}^{\prime}$, no significant differences $(p>0.05)$ were found among samples with low concentration (10.5L and 12L). Among medium concentration samples, only $9 \mathrm{M}$ (low $\mathrm{pH}$ ) differed from $10.5 \mathrm{M}$ and $12 \mathrm{M}$. However, among high concentration samples, there were significant differences, increasing $\mathrm{G}^{\prime}$ when $\mathrm{pH}$ was increased $(9 \mathrm{H}<10.5 \mathrm{H}<12 \mathrm{H})$. Thus, the higher the $\mathrm{pH}$ the more "solid-like" behavior. When comparing the influence of by-product's concentration, no significant differences $(p>0.05)$ were found between $9 \mathrm{M}$ and $9 \mathrm{H}$, but differences were found among samples with $\mathrm{pH} 10.5$ and 12. Elastic shear modulus increased significantly $(p<0.05)$ as by-product's concentration increased.

Regarding the viscous shear modulus $\left(G^{\prime \prime}\right)$, when comparing the influence of the $\mathrm{pH}$ of the aqueous phase, no significant differences $(p>0.05)$ were found between the samples with the lowest concentration of by-product (10.5L and 12L), but differences were found for samples with medium and high concentration. In these samples, $\mathrm{G}^{\prime \prime}$ significantly $(p<0.05)$ increased when increasing the $\mathrm{pH}$ of the aqueous phase. The by-product's concentration does not significantly influence $(p>0.05)$ the samples with the lowest $\mathrm{pH}(9 \mathrm{M}$ and $9 \mathrm{H})$ but had a significant effect $(p<0.05)$ on the samples with medium and high $\mathrm{pH}$. In these samples, the viscous shear modulus significantly increased $(p<0.05)$ as the by-product's 
concentration increased. Therefore, viscoelastic parameters $\left(G^{\prime}\right.$ and $\left.G^{\prime \prime}\right)$ increased their values when increasing the $\mathrm{pH}$ of the aqueous phase and by-product concentration. A local $\mathrm{G}^{\prime \prime}$-maximum appears in Figure 2B on sample 10.5L at $20 \mathrm{~Pa}$. This issue could be related to different factors such as internal friction due to the loss of stability. In general, the values of $\mathrm{G}^{\prime}$ and $\mathrm{G}^{\prime \prime}$ are within the range of emulsions stabilized with plant fibers from by-products (10-1000 Pa [29] and 35-200 Pa [30]). Further, in the work by Huc-Mathis et al. [31], they achieved $\mathrm{G}^{\prime}$ and $\mathrm{G}^{\prime \prime}$ values of 225 and $30 \mathrm{~Pa}$, respectively. This indicates that samples with high concentration and high $\mathrm{pH}$ are strong emulsions formulated with by-products.

Figure 3 shows the flow curves of the different samples. All samples had a shearthinning behavior (i.e., lower viscosity at higher shear rate).
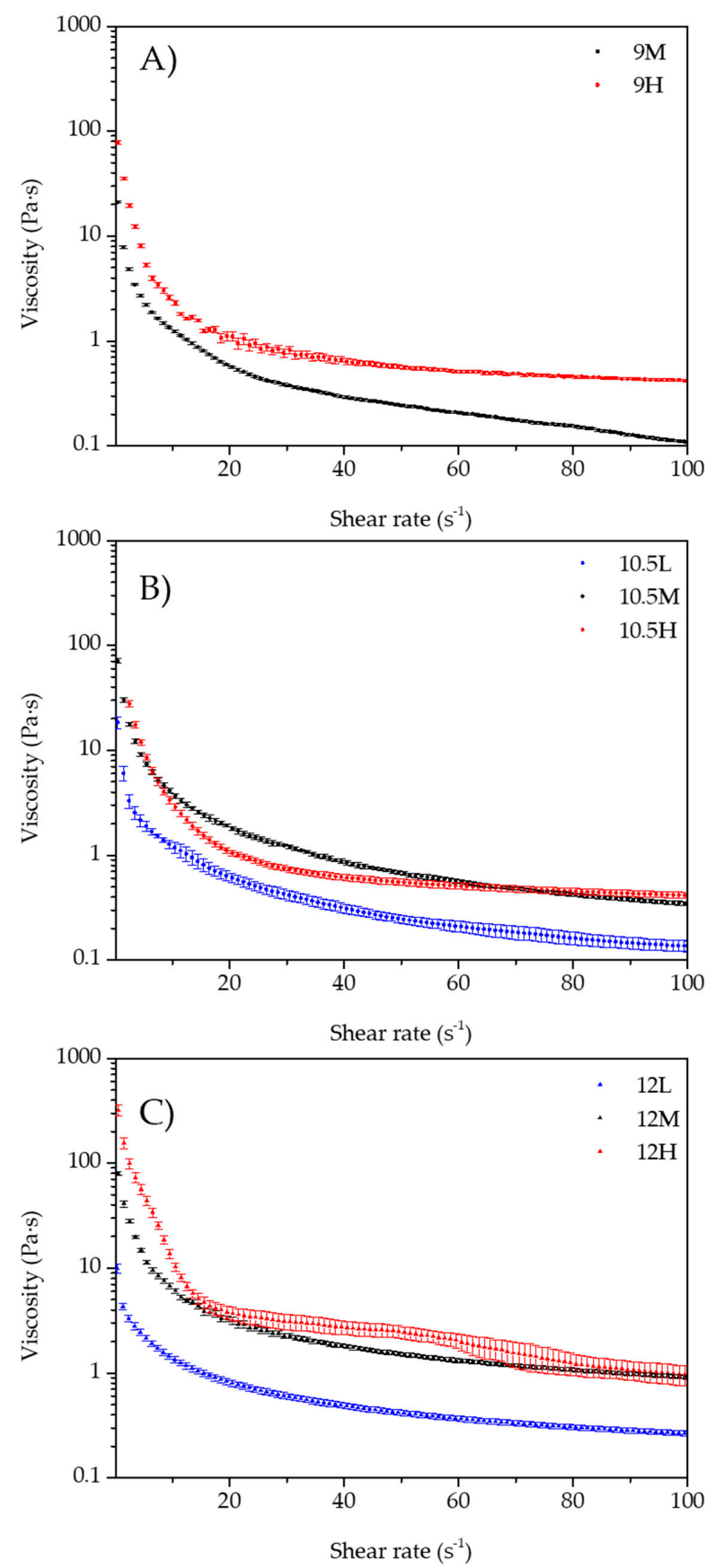

Figure 3. Flow curves of the emulsions. (A) $9 \mathrm{M}$ and 9H; (B) 10.5L, 10.5M, and 10.5H; (C) 12L, 12M, and $12 \mathrm{H}$. 
All samples had similar flow curves, characterized by a rapid decline in the viscosity value at small shear rates and then reaching a stationary value (where the decay was very slow); furthermore, higher viscosities were observed at higher by-product's concentration. Only sample $10.5 \mathrm{H}$ displayed an "anomaly" to this trend, because it showed a lower viscosity value than $10.5 \mathrm{M}$ at less than $50 \mathrm{~s}^{-1}$. After this point, viscosity was like $10.5 \mathrm{M}$ until at the end of the test when its value was slightly higher than $10.5 \mathrm{M}$. The drop of viscosity is caused by the breakdown of the structure when exposed at high shear rates.

The values of viscosity at $50 \mathrm{~s}^{-1}$ are shown in Table 1 and shows the effect of $\mathrm{pH}$ of the aqueous phase was significant $(p<0.05)$ among samples. Furthermore, viscosity values increased when increasing $\mathrm{pH}$; however, the samples $9 \mathrm{H}$ and $10.5 \mathrm{H}$ showed no significant differences $(p>0.05)$. The influence of the by-product's concentration was significant for every $\mathrm{pH}$, i.e., for samples of $\mathrm{pH} 9,10.5$, and 12 significantly higher viscosity values $(p<0.05)$ were observed as the by-product concentration increased. However, as shown in Figure 3B, samples with $\mathrm{pH} 10.5$ presented an "anomaly" as $10.5 \mathrm{H}$ had a viscosity value at $50 \mathrm{~s}^{-1}$ significantly $(p<0.05)$ lower than $10.5 \mathrm{M}$.

These results are related to the microstructure observations, where emulsions with smaller and more packed oil droplets were observed when increasing $\mathrm{pH}$ and the byproduct concentration. Based on Liu et al. [19], this can be linked to the increase in viscosity due to three reasons: (1) the smaller the droplets, the higher the number of interactions per unit of volume; (2) reducing droplets' volume diminishes their deformability because of the increase in Laplace's pressure; and (3) increasing the by-product concentration could cause increased interactions between droplets due to a higher level of flocculation.

Results can also be explained by the effect of increasing the $\mathrm{pH}$ of the aqueous phase on the trub components. Spent brewer's yeast has a content of $40 \%$ crude protein, $59 \%$ carbohydrates and $1 \%$ lipids. Its cell wall is strong, thick, and resistant and has a variable composition, but it is mostly made from $\beta-1,3 / \beta-1,6$ glucans and glycoproteins [32]. Increasing the $\mathrm{pH}$ of the aqueous phase up to 12 probably solubilized proteins and some polysaccharides from the cell wall and degraded the glucose chains from the insoluble compounds [33]. Therefore, different biopolymers from the cell wall can be released to the aqueous phase. The release of glucans to an alkali medium could degrade its structure with a reduction in branching and the break of covalent bonds between mannoproteins and $\beta-1,3 / \beta-1,6$ glucan chains, which decreases de degree of polymerization [32]. Li and Karboune [34] studied the functional properties of mannoproteins from spent brewer's yeast and found an increase in its solubility when increasing $\mathrm{pH}$ from 3 to 9 . We hypothesize that at higher $\mathrm{pH}$ the solubility of mannoproteins increases. Moreover, alkaline treatment cleaves the glycosylphosphatidylinositol anchor between mannoproteins and $\beta$-glucan [32], and therefore, $\beta$-glucans remains insoluble and increase the viscosity of the aqueous phase [33]. Moreover, by adding more by-product, the viscosity of the bulk phase was enhanced. This is likely due to the higher amount of yeast cell debris (an insoluble fraction of the by-product, made from large proteins and polysaccharides) produced during preparing the aqueous phase that improved the stability and also due to the solubilization of proteins which can act as thickeners and emulsifiers [35].

\subsection{Physical Stability}

Physical stability was investigated by determining the oil lost under centrifugal forces (oil loss \%). Interactions $(p<0.05)$ between the by-product's concentration and the $\mathrm{pH}$ of the aqueous phase for oil loss values were observed and shown in Figure 4. In emulsions with $\mathrm{pH} 9$ and 10.5, oil loss values were higher than $50 \%$ regardless of the by-product's concentration, being significantly $(p<0.05)$ higher in emulsions with low concentration. No significant differences $(p>0.05)$ were observed among emulsions produced with medium and high by-product concentration. However, samples with high $\mathrm{pH}(\mathrm{pH} 12)$ were the most stable and showed no significant differences $(p>0.05)$ among them. These results indicate that $\mathrm{pH}$ and concentration have an influence on HIPE gels stability; increasing $\mathrm{pH}$ is the most important factor. HIPE gels with $\mathrm{pH} 12$ were the most stable. 


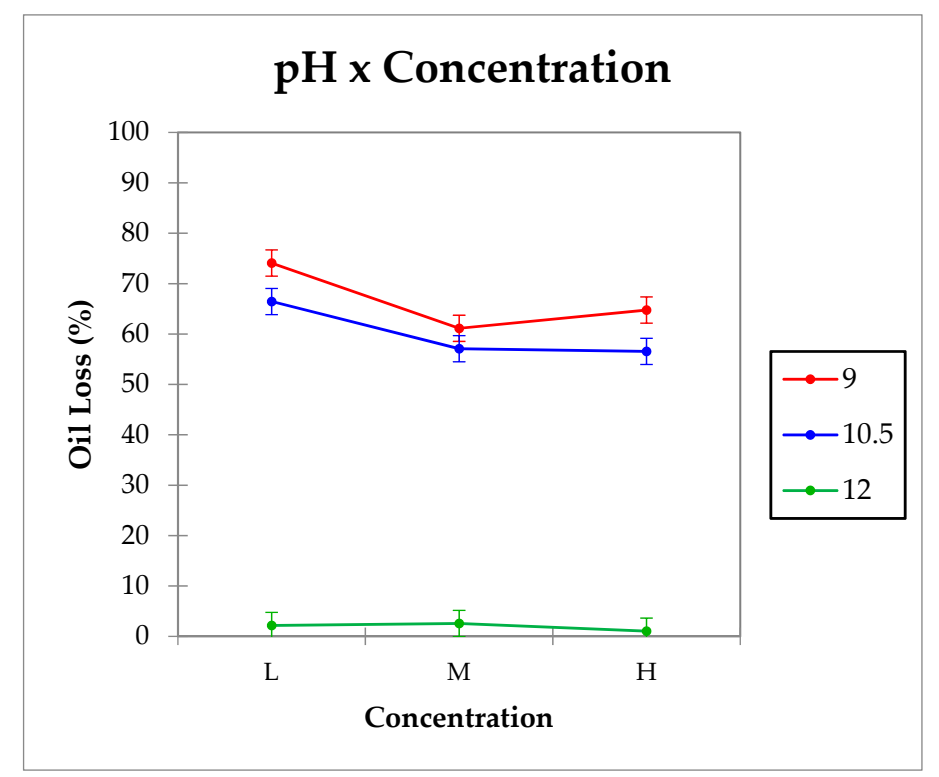

Figure 4. Emulsions oil loss interaction graph.

After centrifugation, three layers were observed in low stability emulsions, shown in Figure 5 . The top layer corresponded to oil, middle layer to the emulsion, and bottom layer to the aqueous phase. Increasing the $\mathrm{pH}$ of the medium increased the stability; this has been attributed by other authors to an increase in the charge density of the proteins which produced higher repulsions among droplets as discussed by Vélez-Erazo et al. [36].

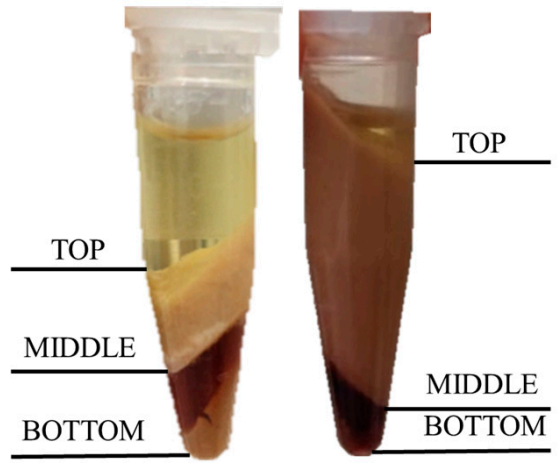

Figure 5. Appearance of the emulsions after centrifugation. (Left) sample 9H; (right) sample 12H. After centrifugation, three layers appeared and were identified.

Stabilizing thermodynamically unstable systems with raw by-products is difficult; therefore, diluted emulsions are usually produced to evaluate their properties. Oil-in-water emulsions $(50 / 50(w t / w t))$ were prepared by Huc-Mathis et al. [31], using plant powders (apple pomace and oat bran) and showed similar $\mathrm{G}^{\prime}$ and $\mathrm{G}^{\prime \prime}$ values to the 9L sample in this study. Joseph et al. [37] also fabricated 10/90 and 50/50 (wt/wt) emulsions using cocoa, rapeseed, and lupin hull powders but no rheological measurements were conducted, although relatively long-term (14-70 days) stable emulsions were produced depending on the plant material used for stabilization. The trend when working with by-products is to produce Pickering emulsions due to the heterogeneous composition of the raw materials consisting of soluble and insoluble compounds.

\subsection{Color Analysis}

Table 2 shows the color parameters $\mathrm{L}^{*}, \mathrm{C}^{*}$, and $\mathrm{h}^{*}$. There were no interactions $(p>0.05)$ between the by-product's concentration and $\mathrm{pH}$ of the aqueous phase for the studied parameters, but both factors had a significant effect $(p<0.05)$ on these parameters. 
Table 2. Color parameters of the emulsions.

\begin{tabular}{cccc}
\hline Sample & $\mathbf{L}^{*}$ & $\mathbf{C}^{*}$ & $\mathbf{h}^{*}$ \\
\hline $9 \mathrm{~L}$ & $55.77(0.73)^{\mathrm{cd}}$ & $18.50(0.96)^{\mathrm{a}}$ & $93.68(1.14)^{\mathrm{f}}$ \\
$9 \mathrm{M}$ & $54.19(1.32)^{\mathrm{bcd}}$ & $21.66(1.24)^{\mathrm{cd}}$ & $89.16(0.52)^{\mathrm{e}}$ \\
$9 \mathrm{H}$ & $47.74(0.93)^{\mathrm{a}}$ & $21.04(0.58)^{\mathrm{bc}}$ & $86.91(0.81)^{\mathrm{e}}$ \\
\hline $10.5 \mathrm{~L}$ & $57.66(0.71)^{\mathrm{d}}$ & $19.80(0.93)^{\mathrm{ab}}$ & $87.29(1.10)^{\mathrm{e}}$ \\
$10.5 \mathrm{M}$ & $53.77(0.77)^{\mathrm{bcd}}$ & $21.93(0.08)^{\mathrm{cd}}$ & $82.27(1.51)^{\mathrm{d}}$ \\
$10.5 \mathrm{H}$ & $50.91(2.86)^{\mathrm{ab}}$ & $22.73(0.89)^{\mathrm{d}}$ & $83.48(1.55)^{\mathrm{d}}$ \\
\hline $12 \mathrm{~L}$ & $56.79(5.08)^{\mathrm{d}}$ & $20.61(0.03)^{\mathrm{bc}}$ & $77.95(1.55)^{\mathrm{c}}$ \\
$12 \mathrm{M}$ & $56.65(3.28)^{\mathrm{d}}$ & $22.97(0.44)^{\mathrm{d}}$ & $71.37(0.50)^{\mathrm{a}}$ \\
$12 \mathrm{H}$ & $52.49(1.52)^{\mathrm{bc}}$ & $24.51(1.29)^{\mathrm{e}}$ & $74.67(0.27)^{\mathrm{b}}$ \\
\hline
\end{tabular}

Different superscript letters within the same column mean significant differences between samples $(p<0.05)$.

Luminosity $\left(\mathrm{L}^{*}\right)$ was mainly influenced by the by-product concentration. All samples had $L^{*}$ values ranging from 45 to 60 , thus, all showed a medium luminosity $(0=$ black; $100=$ white). Regarding the influence of the $\mathrm{pH}$ of the aqueous phase, only significant differences $(p<0.05)$ were found between samples $9 \mathrm{H}$ and $12 \mathrm{H}$, being $\mathrm{L}^{*}$ higher at higher $\mathrm{pH}$. When comparing emulsions with the same $\mathrm{pH}$, samples with a higher concentration $(9 \mathrm{H}$ and $12 \mathrm{H})$ had inferior $\mathrm{L}^{*}$ values $(p<0.05)$ than those with low concentration (9L and 12L). No significant differences $(p>0.05)$ were found among emulsions with low and medium by-product concentration for the same $\mathrm{pH}$ value.

The chroma $\left(C^{*}\right)$ parameter had a similar but inverse behavior than lightness because chroma only depends on the light removed by scattering, whereas the lightness also is influenced by the direction where the light is scattered [38]. When the effect of the $\mathrm{pH}$ of the aqueous phase was assessed for emulsions with the same by-product concentration, significant differences $(p<0.05)$ were observed among samples with low (9L and $12 \mathrm{~L})$ and high concentration $(9 \mathrm{H}$ and $12 \mathrm{H})$. $\mathrm{C}^{*}$ value increased $(p<0.05)$ when increasing $\mathrm{pH}$, except for the medium by-product concentrations. When comparing emulsions with the same $\mathrm{pH}$, at low and medium $\mathrm{pH}$ there were differences $(p<0.05)$ between samples with low and high concentration, being $C^{*}$ higher in emulsions with high concentration. No differences were found $(p>0.05)$ among samples with medium and high by-product concentration, except for $\mathrm{pH} 12$ where significant differences $(p<0.05)$ among the three emulsions were detected, increasing $C^{*}$ when increasing by-product's concentration. Generally, $C^{*}$ values increased both as the by-product's concentration and the $\mathrm{pH}$ of the aqueous phase increased. Umaña et al. [39] prepared oil-in-water emulsions using a concentrate of mushroom byproducts and indicated that increasing the concentration of the concentrate produced a decrease in $\mathrm{L}^{*}$ and an increase in $\mathrm{a}^{*}$ and $\mathrm{b}^{*}$, thus $\mathrm{C}^{*}$ increased.

Finally, for most emulsions, the hue angle $\left(\mathrm{h}^{*}\right)$ value ranged from $70^{\circ}$ to $90^{\circ}$ (Table 2). Only sample $9 \mathrm{~L}$ had a higher value than $90^{\circ}$. This emulsion had a yellow-greenish color. However, the rest of the samples were in the red-yellow range, so most emulsions presented orange tones. Increasing the $\mathrm{pH}$ of the aqueous phase of the emulsion showed more reddish emulsions. In terms of by-product concentration, when comparing emulsions with the same $\mathrm{pH}$, the increase in by-product's concentration also generated more reddish emulsions. However, no significant differences were found $(p<0.05)$ between the $9 \mathrm{M}$ and $9 \mathrm{H}$ emulsions, nor between the $10.5 \mathrm{M}$ and $10.5 \mathrm{H}$ emulsions. All the emulsions formulated at $\mathrm{pH} 12$ showed significant differences $(p<0.05)$ between them, being those made with a lower concentration of by-product $(12 \mathrm{~L})$ present significantly $(p<0.05)$ higher values of $h^{*}$. The influence of by-product concentration on the hue angle appeared to be greater at high aqueous solution $\mathrm{pH}$ values. The reason behind the diminution of $\mathrm{h}$ when increasing the $\mathrm{pH}$, making samples more orange, might be due to the effect of the $\mathrm{pH}$ on hop particles. According to Verzele et al. [40], spent hops are a rich source of xanthohumol. An increase in the medium's $\mathrm{pH}$ favors the separation of this flavonoid from the cell wall. This compound, when in solution, exhibits a deep red color, which might explain the change in the hue angle to reddish tones. 


\section{Conclusions}

The increase in by-product concentration and the $\mathrm{pH}$ of the aqueous phase allowed development of HIPE gels with structural and physical stability, with homogeneously distributed oil droplets of regular size and polyhedral structure.

Rheology data proved a more stable structure at higher $\mathrm{pH}$ and higher by-product concentration due to the higher amount of yeast cell debris and the cleavage of the yeast cell wall that releases intracellular compounds. This release increased the viscosity of the aqueous phase and mannoprotein's solubility. Luminosity decreased when the byproduct's concentration increased. Increasing by-product concentration and the $\mathrm{pH}$ of the aqueous phase increased chroma values and diminished hue value angle, favoring the development of orange-colored emulsions.

This study widens the possibilities to valorize the by-products from the modern brewing industry as stabilizers when designing emulsions. However, further investigation should be conducted to expand the knowledge of these by-products for designing HIPE gels for its implementation on an industrial scale.

\section{Materials and Methods}

\subsection{Materials}

The by-product mixture of trub and spent brewer yeast was kindly supplied by TYRIS Craft \& Creative Beers (Valencia, Spain). Refined sunflower oil (Hacendado, Valencia, Spain) was acquired from a supermarket and distilled water was used throughout this study.

\subsection{Methods}

\subsubsection{By-Products' Powder Preparation}

The mixture of trub and spent yeast was stored at $-8^{\circ} \mathrm{C}$ immediately after collection from its production tank to prevent microbial growth. The sample was defrosted and centrifuged (Sorvall Super T21, GMI, Ramsey, NJ, USA) at $17,000 \times \mathrm{g}$ for $10 \mathrm{~min}$ at $4{ }^{\circ} \mathrm{C}$ to remove residual beer liquor. Then, it was vacuum dried (Vaciotem-T, J.P. SELECTA, Barcelona, Spain) at $40{ }^{\circ} \mathrm{C}$ and -0.7 bar until reaching constant weight. After that, the mixture was milled using a thermostatic grinder (IKA M20, Staufen, Germany) to reduce the powder's size before ball milled.

The water content of the powder was determined after vacuum drying (VaciotemT) at $60{ }^{\circ} \mathrm{C}$ for $24 \mathrm{~h}$. Particle size was determined using a vibratory sieve shaker with automatic amplitude control (RP 200N SILENT, CISA, Barcelona, Spain). Color attributes $\left(\right.$ CIEL $^{*} \mathrm{a}^{*} \mathrm{~b}^{*}$, standard light source D65 and standard observer $10^{\circ}$ ) were measured with a spectrophotocolorimeter Minolta CR-400 (Konica Minolta Sensing, Inc., Osaka, Japan).

\subsubsection{Dispersion and High Internal Phase Emulsion Gels Preparation}

Powder was dispersed in water and stirred for $1 \mathrm{~h}$ to ensure complete dissolution. Then, $\mathrm{pH}$ was set by carefully adding $6 \mathrm{M} \mathrm{NaOH}$. After, the aqueous phase was stirred with a magnetic stirrer for $2 \mathrm{~h}$ at room temperature $\left(20-25^{\circ} \mathrm{C}\right)$. The homogenization process was conducted using an Ultra-Turrax (Ultraturrax T18, IKA, Staufen, Germany) with a rotor dispersor of $12.7 \mathrm{~mm}$, based on the procedure described by Wijaya et al. [41] with slight modifications. Briefly, $5 \mathrm{~g}$ of the aqueous phase was dispersed for $30 \mathrm{~s}$ at $8000 \mathrm{rpm}$, then $20 \mathrm{~g}$ of oil was slowly added to the water phase at $14,000 \mathrm{rpm}$. Once all the oil phase was added, the homogenization process ended with $30 \mathrm{~s}$ at 16,000 rpm. The self-standing emulsions were stored at $4{ }^{\circ} \mathrm{C}$ before analysis on the following day.

According to $\mathrm{pH}$ and concentration, nine samples were evaluated and named, as shown in Table 3. All analyzes were carried out in triplicate. 
Table 3. Naming and composition of the samples according to the $\mathrm{pH}$ of the aqueous phase and the concentration of by-product in emulsions.

\begin{tabular}{ccccccccccc}
\hline & \multicolumn{3}{c}{ pH 9 } & \multicolumn{3}{c}{ pH 10.5 } & \multicolumn{3}{c}{ pH 12 } \\
\cline { 2 - 10 } & $\mathbf{9 L}$ & $\mathbf{9 M}$ & $\mathbf{9 H}$ & $\mathbf{1 0 . 5 L}$ & $\mathbf{1 0 . 5 M}$ & $\mathbf{1 0 . 5 H}$ & $\mathbf{1 2 L}$ & $\mathbf{1 2 M}$ & $\mathbf{1 2 H}$ \\
\hline By-product's & 1 & 2.5 & 4 & 1 & 2.5 & 4 & 1 & 2.5 & 4 \\
concentration (\%) & & & & & & & & & & \\
Sunflower oil (\%) & 80 & 80 & 80 & 80 & 80 & 80 & 80 & 80 & 80 \\
Water (\%) & 19 & 17.5 & 16 & 19 & 17.5 & 16 & 19 & 17.5 & 16 \\
\hline
\end{tabular}

\subsubsection{Microstructure}

The microstructure was studied using a Cryo-field emission scanning electron microscopy. The samples were frozen by immersion in slush nitrogen and after being fractured, etched, and coated with platinum, they were observed at $15 \mathrm{kV}$ at a working distance of $15 \mathrm{~mm}$ in a microscope Ultra55 FESEM (Zeiss, Oberkochen, Germany).

\subsubsection{Rheological Behavior}

A rotational rheometer (Kinexus Pro+, Malvern Panalytical, Worcestershire, UK), equipped with a Peltier plate cartridge was used to perform tests at $5{ }^{\circ} \mathrm{C}$ [41,42]. A $40 \mathrm{~mm}$ diameter plate-plate sensor geometry and $1 \mathrm{~mm}$ gap were used. Samples were left for $3 \mathrm{~min}$ to rest after reaching the desired gap. Amplitude sweeps $(0.01-100 \mathrm{~Pa}, 1 \mathrm{~Hz})$, frequency sweeps $(0.1-10 \mathrm{~Hz}, 1 \mathrm{~Pa})$, and flow curves $\left(0.1-100 \mathrm{~s}^{-1}\right)$ were conducted.

\subsubsection{Physical Stability}

Determination was made by measuring the oil lost under centrifugal forces according to the method of Vélez-Erazo et al. [35] with minor modifications. Briefly, approximately $1 \mathrm{~g}$ of emulsion was inserted in a $1.5 \mathrm{~mL}$ Eppendorf tube and centrifuged at $11,200 \times \mathrm{g}$ for $30 \mathrm{~min}$ at $4{ }^{\circ} \mathrm{C}$. Free oil was carefully removed with a Pasteur pipette. Results (expressed as $\mathrm{g}$ of oil loss per $100 \mathrm{~g}$ of sample) were calculated using Equation (1), where $\mathrm{m}_{\mathrm{i}}$ refers to the weight of the tube with emulsion, $\mathrm{m}_{\mathrm{f}}$ refers to the tube with emulsion after centrifugation and free oil removal, and $\mathrm{m}$ refers to the weight of the Eppendorf tube.

$$
\text { Oil Loss }(\%)=\frac{m_{i}-m_{f}}{m_{i}-m} \times 100
$$

\subsubsection{Color Analysis}

For color determination of emulsions, a Minolta CM-3600d spectrocolorimeter (Minolta Co., Tokyo, Japan) was used. Emulsions were placed over $40 \mathrm{~mm} \times 12 \mathrm{~mm}$ soda-lime glass Petri dishes and covered, ensuring no appearance of bubbles. Color was measured using the CIEL*a*b* color coordinates considering the standard light source D65 and the standard observer $10^{\circ}$. In this system, $\mathrm{L}^{*}$ indicates the level of lightness/darkness, $\mathrm{C}^{*}$ is related to the purity of the color, and the hue angle $\left(\mathrm{h}^{*}\right)$ shows the tonality of the color.

\subsubsection{Statistical Analysis}

A categorical multifactorial experimental design with two factors- $\mathrm{pH}$ of the aqueous phase and concentration of the by-product-was used to characterize all samples. Analysis of variance (ANOVA) was performed on the data. The least significant differences (Fisher's LSD test) with a $95 \%$ confidence were used to compare the obtained mean values $(p<0.05)$.

All the data were analyzed using XLSTAT 2018.1 (Addinsoft, Barcelona, Spain).

Author Contributions: A.L.-G.: investigation, validation, data curation and writing-original draft preparation. G.M.: methodology, formal analysis, and writing-review and editing. I.H.: conceptualization, supervision, writing-review and editing, and funding acquisition. A.Q.: conceptualization, supervision, writing-review and editing, and funding acquisition. All authors have read and agreed to the published version of the manuscript. 
Funding: Grant RTI-2018-099738-B-C22 funded by MCIN/AEI/ 10.13039/501100011033 and “ERDF A way of making Europe".

Institutional Review Board Statement: Not applicable.

Informed Consent Statement: Not applicable.

Data Availability Statement: Research data are not shared.

Acknowledgments: The authors thank Phillip Bentley for assistance in correcting the manuscript's English.

Conflicts of Interest: The authors declare no conflict of interest.

\section{References}

1. Olajire, A.A. The Brewing Industry and Environmental Challenges. J. Clean. Prod. 2020, 256, 102817. [CrossRef]

2. dos Santos Mathias, T.R.; de Mello, P.P.M.; Servulo, E.F.C. Solid Wastes in Brewing Process: A Review. J. Brew. Distill. 2014, 5, 1-9. [CrossRef]

3. Esparza, I.; Jiménez-Moreno, N.; Bimbela, F.; Ancín-Azpilicueta, C.; Gandía, L.M. Fruit and Vegetable Waste Management: Conventional and Emerging Approaches. J. Environ. Manag. 2020, 265, 110510. [CrossRef] [PubMed]

4. Ferreira, I.M.P.L.V.O.; Pinho, O.; Vieira, E.; Tavarela, J.G. Brewer's Saccharomyces Yeast Biomass: Characteristics and Potential Applications. Trends Food Sci. Technol. 2010, 21, 77-84. [CrossRef]

5. Rakowska, R.; Sadowska, A.; Dybkowska, E.; Świderski, F. Spent Yeast as Natural Source of Functional Food Additives. Roczniki Panstwowego Zakladu Higieny 2017, 68, 115-121.

6. Bedini, S.; Flamini, G.; Girardi, J.; Cosci, F.; Conti, B. Not Just for Beer: Evaluation of Spent Hops (Humulus Lupulus L.) as a Source of Eco-Friendly Repellents for Insect Pests of Stored Foods. J. Pest Sci. 2015, 88, 583-592. [CrossRef]

7. Senna Ferreira Costa, F.; Roquete Amparo, T.; Brandão Seibert, J.; Silveira, B.M.; Gomes da Silva, R.; Inocêncio Pereira, D.; Gontijo Garcia Barbosa, R.; dos Santos, O.D.H.; Brandão, G.C.; de Medeiros Teixeira, L.F.; et al. Reuse of Hot Trub as an Active Ingredient with Antioxidant and Antimicrobial Potential. Waste Biomass Valorization 2021, 12, 2037-2047. [CrossRef]

8. Saraiva, B.R.; Anjo, F.A.; Vital, A.C.P.; Silva, L.H.M.D.; Ogawa, C.Y.L.; Sato, F.; Coimbra, L.B.; Matumoto-Pintro, P.T. Waste from Brewing (Trub) as a Source of Protein for the Food Industry. Int. J. Food Sci. Technol. 2019, 54, 1247-1255. [CrossRef]

9. Karlović, A.; Jurić, A.; Ćorić, N.; Habschied, K.; Krstanović, V.; Mastanjević, K. By-Products in the Malting and Brewing Industries-Re-Usage Possibilities. Fermentation 2020, 6, 82. [CrossRef]

10. Marson, G.V.; de Castro, R.J.S.; Belleville, M.P.; Hubinger, M.D. Spent Brewer's Yeast as a Source of High Added Value Molecules: A Systematic Review on Its Characteristics, Processing and Potential Applications. World J. Microbiol. Biotechnol. $2020,36,95$. [CrossRef]

11. Saraiva, B.R.; da Silva, L.H.M.; Anjo, F.A.; Vital, A.C.P.; da Silva, J.B.; Bruschi, M.L.; Matumoto Pintro, P.T. Technological and Sensorial Properties of Liquid Nitrogen Ice Cream Enriched with Protein from Brewing Waste (Trub). Int. J. Food Sci. Technol. 2020, 55, 1962-1970. [CrossRef]

12. da Silva Araújo, V.B.; de Melo, A.N.F.; Costa, A.G.; Castro-Gomez, R.H.; Madruga, M.S.; de Souza, E.L.; Magnani, M. Followed Extraction of $\beta$-Glucan and Mannoprotein from Spent Brewer's Yeast (Saccharomyces Uvarum) and Application of the Obtained Mannoprotein as a Stabilizer in Mayonnaise. Innov. Food Sci. Emerg. Technol. 2014, 23, 164-170. [CrossRef]

13. de Melo, A.N.F.; de Souza, E.L.; da Silva Araujo, V.B.; Magnani, M. Stability, Nutritional and Sensory Characteristics of French Salad Dressing Made with Mannoprotein from Spent Brewer's Yeast. LWT-Food Sci. Technol. 2015, 62, 771-774. [CrossRef]

14. Paramera, E.I.; Karathanos, V.T.; Konteles, S.J. Yeast Cells and Yeast-Based Materials for Microencapsulation. In Microencapsulation in the Food Industry; Elsevier: Amsterdam, The Netherlands, 2014; pp. 267-281.

15. Worrasinchai, S.; Suphantharika, M.; Pinjai, S.; Jamnong, P. $\beta$-Glucan Prepared from Spent Brewer's Yeast as a Fat Replacer in Mayonnaise. Food Hydrocoll. 2006, 20, 68-78. [CrossRef]

16. Gao, H.; Ma, L.; Cheng, C.; Liu, J.; Liang, R.; Zou, L.; Liu, W.; McClements, D.J. Review of Recent Advances in the Preparation, Properties, and Applications of High Internal Phase Emulsions. Trends Food Sci. Technol. 2021, 112, 36-49. [CrossRef]

17. Bascuas, S.; Morell, P.; Hernando, I.; Quiles, A. Recent Trends in Oil Structuring Using Hydrocolloids. Food Hydrocolloids 2021, 118, 106612. [CrossRef]

18. Yan, C.; Wu, X.; Wang, Y.; Peng, S.; Chen, J.; Zou, L.; McClements, D.J.; Liu, W. Utilization of Polysaccharide-Based High Internal Phase Emulsion for Nutraceutical Encapsulation: Enhancement of Carotenoid Loading Capacity and Stability. J. Funct. Foods 2021, 84, 104601. [CrossRef]

19. Liu, W.; Gao, H.; McClements, D.J.; Zhou, L.; Wu, J.; Zou, L. Stability, Rheology, and $\beta$-Carotene Bioaccessibility of High Internal Phase Emulsion Gels. Food Hydrocoll. 2019, 88, 210-217. [CrossRef]

20. Miao, J.; Xu, N.; Cheng, C.; Zou, L.; Chen, J.; Wang, Y.; Liang, R.; McClements, D.J.; Liu, W. Fabrication of Polysaccharide-Based High Internal Phase Emulsion Gels: Enhancement of Curcumin Stability and Bioaccessibility. Food Hydrocoll. 2021, 117, 106679. [CrossRef]

21. Gutiérrez-Luna, K.; Astiasarán, I.; Ansorena, D. Gels as Fat Replacers in Bakery Products: A Review. Crit. Rev. Food Sci. Nutr. 2021, 1-14. [CrossRef] 
22. Chen, X.W.; Fu, S.Y.; Hou, J.J.; Guo, J.; Wang, J.M.; Yang, X.Q. Zein Based Oil-in-Glycerol Emulgels Enriched with $\beta$-Carotene as Margarine Alternatives. Food Chem. 2016, 211, 836-844. [CrossRef]

23. Carpes, S.T.; Bertotto, C.; Bilck, A.P.; Yamashita, F.; Anjos, O.; Bakar Siddique, M.A.; Harrison, S.M.; Brunton, N.P. Bio-Based Films Prepared with Apple Pomace: Volatiles Compound Composition and Mechanical, Antioxidant and Antibacterial Properties. LWT 2021, 144, 111241. [CrossRef]

24. Jayesree, N.; Hang, P.K.; Priyangaa, A.; Krishnamurthy, N.P.; Ramanan, R.N.; Turki, M.S.A.; Charis, M.G.; Ooi, C.W. Valorisation of Carrot Peel Waste by Water-Induced Hydrocolloidal Complexation for Extraction of Carote and Pectin. Chemosphere 2021, 272, 129919. [CrossRef]

25. Johansson, M.; Xanthakis, E.; Langton, M.; Menzel, C.; Vilaplana, F.; Johansson, D.P.; Lopez-Sanchez, P. Mixed Legume Systems of Pea Protein and Unrefined Lentil Fraction: Textural Properties and Microstructure. LWT 2021, 144, 111212. [CrossRef]

26. Ramos-Andrés, M.; Aguilera-Torre, B.; García-Serna, J. Hydrothermal Production of High-Molecular Weight Hemicellulose-Pectin, Free Sugars and Residual Cellulose Pulp from Discarded Carrots. J. Clean. Prod. 2021, 290, 125179. [CrossRef]

27. Huc-Mathis, D.; Almeida, G.; Michon, C. Pickering Emulsions Based on Food Byproducts: A Comprehensive Study of Soluble and Insoluble Contents. J. Colloid Interface Sci. 2021, 581, 226-237. [CrossRef] [PubMed]

28. Rowe, E.L. Effect of Emulsifier Concentration and Type on the Particle Size Distribution of Emulsions. J. Pharm. Sci. 1965, 54, 260-264. [CrossRef] [PubMed]

29. Winuprasith, T.; Suphantharika, M. Microfibrillated Cellulose from Mangosteen (Garcinia mangostana L.) Rind: Preparation, Characterization, and Evaluation as an Emulsion Stabilizer. Food Hydrocoll. 2013, 32, 383-394. [CrossRef]

30. Basanta, M.F.; de Escalada Plá, M.F.; Raffo, M.D.; Stortz, C.A.; Rojas, A.M. Cherry Fibers Isolated from Harvest Residues as Valuable Dietary Fiber and Functional Food Ingredients. J. Food Eng. 2014, 126, 149-155. [CrossRef]

31. Huc-Mathis, D.; Journet, C.; Fayolle, N.; Bosc, V. Emulsifying Properties of Food By-Products: Valorizing Apple Pomace and Oat Bran. Colloids Surf. A Physicochem. Eng. Asp. 2019, 568, 84-91. [CrossRef]

32. Avramia, I.; Amariei, S. Spent Brewer's Yeast as a Source of Insoluble $\beta$-Glucans. Int. J. Mol. Sci. 2021, 22, 825. [CrossRef]

33. Pinto, M.; Coelho, E.; Nunes, A.; Brandão, T.; Coimbra, M.A. Valuation of Brewers Spent Yeast Polysaccharides: A Structural Characterization Approach. Carbohydr. Polym. 2015, 116, 215-222. [CrossRef]

34. Li, J.; Karboune, S. Characterization of the Composition and the Techno-Functional Properties of Mannoproteins from Saccharomyces Cerevisiae Yeast Cell Walls. Food Chem. 2019, 297, 124867. [CrossRef] [PubMed]

35. Vélez-Erazo, E.M.; Bosqui, K.; Rabelo, R.S.; Kurozawa, L.E.; Hubinger, M.D. High Internal Phase Emulsions (HIPE) Using Pea Protein and Different Polysaccharides as Stabilizers. Food Hydrocoll. 2020, 105, 105775. [CrossRef]

36. Vélez-Erazo, E.M.; Saturno, R.P.; Marson, G.V.; Hubinger, M.D. Spent Brewer's Yeast Proteins and Cell Debris as Innovative Emulsifiers and Carrier Materials for Edible Oil Microencapsulation. Food Res. Int. 2020, 140, 109853. [CrossRef]

37. Joseph, C.; Savoire, R.; Harscoat-Schiavo, C.; Pintori, D.; Monteil, J.; Faure, C.; Leal-Calderon, F. Pickering Emulsions Stabilized by Various Plant Materials: Cocoa, Rapeseed Press Cake and Lupin Hulls. LWT 2020, 130, 109621. [CrossRef]

38. McClements, D.J. Food Emulsions; CRC Press: Boca Raton, FL, USA, 2004; ISBN 9780429123894.

39. Umaña, M.; Turchiuli, C.; Eim, V.; Rosselló, C.; Simal, S. Stabilization of Oil-in-Water Emulsions with a Mushroom (Agaricus Bisporus) by-Product. J. Food Eng. 2021, 307, 110667. [CrossRef]

40. Verzele, M.; Stockx, J.; Fontijn, F.; Anteunis, M. Xanthohumol, a New Natural Chalkone. Bull. Des Sociétés Chim. Belg. 1957, 66, 452-475. [CrossRef]

41. Wijaya, W.; Sun, Q.Q.; Vermeir, L.; Dewettinck, K.; Patel, A.R.; van der Meeren, P. PH and Protein to Polysaccharide Ratio Control the Structural Properties and Viscoelastic Network of HIPE-Templated Biopolymeric Oleogels. Food Struct. 2019, $21,100112$. [CrossRef]

42. Wijaya, W.; der Meeren, P.; Wijaya, C.H.; Patel, A.R. High Internal Phase Emulsions Stabilized Solely by Whey Protein Isolate-Low Methoxyl Pectin Complexes: Effect of PH and Polymer Concentration. Food Funct. 2017, 8, 584-594. [CrossRef] 